\title{
Letrozole Versus Clomiphene Citrate for Superovulation in Intrauterine Insemination Cycles - Retrospective Comparative Study Conducted in the Department of Reproductive Medicine, Mahatma Gandhi Medical College \& Hospital, Jaipur
}

\author{
Jawahira Chishtiㄹ, Jai Chowdhary², Archana Paliwal ${ }^{3}$, Chetan Kumar Sharma ${ }^{4}$, Manisha Choudhary ${ }^{5}$
}

\begin{abstract}
${ }^{1}$ Department of Obst. \& Gynae, Mahatma Gandhi Medical College \& Hospital, Sitapura, Tonk Road, Jaipur, Rajasthan, India, ${ }^{2}$ Department of Radiology, Mahatma Gandhi Medical College \& Hospital, Sitapura, Tonk Road, Jaipur, Rajasthan, India, ${ }^{3,4}$ Department of PSM, Mahatma Gandhi Medical College \& Hospital, Sitapura, Tonk Road, Jaipur , Rajasthan, India, ${ }^{5}$ Department of Reproductive Medicine, Mahatma Gandhi Medical College \& Hospital, Sitapura, Tonk Road, Jaipur, Rajasthan, India.
\end{abstract}

\section{ABSTRACT}

\section{BACKGROUND}

Superovulation with intrauterine insemination (IUI) increases the probability of pregnancy by increasing number of oocytes and sperm density. The main oral agents used for superovulation are clomiphene citrate and letrozole. Clomiphene citrate a selective estrogen receptor modulator with predominant antiestrogenic action has adverse effects on endometrium and cervical mucous. Letrozole an aromatase inhibitor acts by reducing estrogen production by blocking androgen conversion to estrogen in ovary and peripheral tissues without affecting endometrium and cervical mucous. We wanted to compare the efficacy of letrozole v/s clomiphene citrate as first line ovulation induction drug in infertile patients undergoing IUI.

\section{METHODS}

Based on the inclusion and exclusion criteria, we included 160 patients in our study. They were divided into two groups of 80 each based on the drug given for ovulation induction. The drug was given for 5 days from D3 to D7 of menstrual cycle. IUI was done 38 - 40 hours after trigger and after confirmation of ovulation by sonography.

\section{RESULTS}

The mean age, body mass index (BMI), duration of infertility, type and cause of infertility in both groups were similar. Ovulation rate was $85 \%$ in letrozole group and $71.25 \%$ in clomiphene citrate group, which was statistically significant (P0.035). There was no statistically significant difference between endometrial thickness and total days till ovulation between two groups. Monofolliculogenesis and clinical pregnancy rate were statistically significantly higher in letrozole group.

\section{CONCLUSIONS}

Our study shows that letrozole has better pregnancy rate in comparison to clomiphene citrate (C. C.) in IUI cycles with less risk of anovulation, thin endometrium and multi follicular growth.

\section{KEY WORDS}

Clomiphene Citrate (C.C.), Letrozole (LTZ), Ovulation Induction (OI), Intrauterine Insemination (IUI)
Corresponding Author:

Dr. Manisha Choudhary,

20/133, Kaveri Path,

Mansarovar, Jaipur - 302020,

Rajasthan, India.

E-mail: drmanishachowdhary@gmail.com

DOI: $10.14260 /$ jemds/2021/408

How to Cite This Article:

Chishti J, Chowdhary J, Paliwal A, et al Letrozole versus clomiphene citrate for superovulation in intrauterine insemination cycles - retrospective comparative study conducted in the department of reproductive medicine, Mahatma Gandhi medical college \& hospital, Jaipur. J Evolution Med Dent Sci 2021;10(27):1991-1995, 10.14260/jemds/2021/408

Submission 01-02-2021, Peer Review 08-05-2021 Acceptance 13-05-2021, Published 05-07-2021.

Copyright (C) 2021 Jawahira Chishti et al. This is an open access article distributed under Creative Commons Attribution License [Attribution 4.0 International (CC $B Y 4.0)]$ 


\section{BACKGROUND}

Superovulation with IUI is usually taken as first line treatment in non tubal infertilities like mild PCOS, mild endometriosis, mild male factor and unexplained infertility, where patient fails to conceive after reasonable trial of conservative treatment i.e. superovulation followed by timed intercourse. Superovulation with IUI augments the probability of pregnancy by increasing the number of oocytes and density of motile sperms available to these oocytes. ${ }^{1,2}$

The two main oral agents for superovulation are clomiphene citrate (C. C.) and letrozole (LTZ). Clomiphene citrate has been the most widely used first line drug for superovulation in infertile patients, both for timed intercourse as well as IUI since its introduction in 1960's. 3,4 The different indications for its use are polycystic ovarian syndrome (PCOS), unexplained infertility, IUI and mild stimulation protocols in in-vitro fertilization (IVF). It is a non-steroidal selective estrogen receptor modulator with predominant antiestrogenic action. Clomiphene citrate has a long half-life around 2 weeks resulting in long lasting estrogen receptor depletion and antiestrogenic adverse effects on endometrium, ${ }^{5}$ and cervical mucus. ${ }^{6}$ Anovulation even with high doses is seen in $20-25 \%$ cases know as clomiphene citrate resistance. Discrepancy in ovulation and pregnancy rate (60 - $85 \% \mathrm{~V} / \mathrm{s} 1020 \%)$ is another problem seen with clomiphene citrate known as clomiphene citrate failure. Miscarriage rate is also higher with clomiphene citrate. So the need for an alternative to clomiphene citrate for ovulation induction was realized since 1990's.

Robert Casper and mohmed F. M. mitwally of Toronto general hospital are credited for proposing the concept of aromatase inhibitor i.e letrozole as an alternative to clomiphene citrate for ovulation induction in women with clomiphene citrate failure or resistance. Letrozole (Femara) was an orally active drug used for the treatment of metastatic breast cancer in receptor positive or post menopausal females. Letrozole acts by reducing estrogen production by blocking androgen to estrogen conversion in ovary and peripheral tissues. So it has no antiestrogenic effects on endometrium and cervical mucus. ${ }^{7}$ Additionally the response is more physiological as it doesn't block estrogen receptors at the level of hypothalamus and pituitary and thus keeps the feedback loop patent. So the induction mostly ends up with monofollicular growth $(60-80 \%)$. Letrozole has a short halflife i.e. around 48 hours, so effect of drug easily vanes off. Increased levels of intraovarian androgens augment the follicular sensitivity to FSH and stimulates insulin like growth factor (IGF - 1) as well, which helps in follicular growth. ${ }^{8}$ After similar studies letrozole was shown to be very effective both in ovulation rate and live birth rate. But its use was banned in most of the countries including India after Dr. Marinko Biljan of Montreal presented an oral abstract in 2005 ASRM annual meeting, reporting congenital anomalies in 150 babies born from infertile women treated with letrozole. ${ }^{9}$ Later on larger studies with better designs have been published regarding safety of letrozole as ovulation induction drug. ${ }^{10}$ Some of them even reported higher incidence of congenital malformation with clomiphene citrate. ${ }^{11}$ In India letrozole was approved for ovulation induction from 2006 to October 2011 by Drug controller general of India (DCGI). The ban was lifted by Union health ministry on recommendation of Drug technical advisory board (DTAB) in February 2017 after a large population based study regarding safety of letrozole. There are many comparative studies done for letrozole and clomiphene citrate as first line ovulation induction drug for controlled ovarian hyper stimulation but most of them found both the drugs comparable. ${ }^{12}$

\section{Objective}

The study was done to compare the efficacy of letrozole V / S clomiphene citrate as first line ovulation induction drug in infertile patients undergoing IUI.

\section{METHODS}

This is a retrospective comparative study conducted in Reproductive Medicine department of Mahatma Gandhi medical college and Hospital from January 2019 to November 2019. Study protocol was approved by the institutional ethical committee.

Based on the inclusion and exclusion criteria, the total number of patients available for our study were 160 .

\section{Inclusion Criteria \\ 1. Patients with oligoovulation and menstrual irregularities. \\ 2. Male factor with oligospermia. \\ 3. Patients with unexplained infertility.}

\section{Exclusion Criteria}

1. Age $>35$ years

2. Poor ovarian Reserve $(\mathrm{FSH}>10 \mathrm{mIU} / \mathrm{ml})$

3. Infertility $>5$ years

4. H / O of Genital Koch's

5. Moderate to severe endometriosis or PCOS

6. H / O Chronic Pelvic inflammatory disease (PID)

7. $\mathrm{H} / \mathrm{O}$ OCP use in previous cycle

Each patient was evaluated by detailed history, physical examination, routine investigations, baseline FSH levels and antral follicle count (AFC) on transvaginal sonography (TVS). The tubal patency was confirmed by either HSG or VHL. Detailed evaluation of male partner was also done specially in cases of male factor infertility.

Patients were divided into two groups of 80 each based on the odd and even numbers. Patients in group - 1 were given clomiphene citrate $(50-100 \mathrm{mg}$ ) from day 3 to day 7 and patients in group - 2 were given letrozole $(2.5-5 \mathrm{mg}$ ) from day 3 to day 7. The dose was decided according to age, BMI, baseline FSH and AFC. Follicular monitoring details were taken by TVS from day 10 and continued till mature follicle was $>18 \mathrm{~mm}$. A single injection of HCG $10000 \mathrm{IU}$ was given as trigger in the evening between $6 \mathrm{PM}$ and $8 \mathrm{PM}$ and IUI was planned 38 - 40 hours after the trigger. Ovulation was confirmed by transabdominal sonography before IUI. Luteal support was given as vaginal micronized progesterone 200 microgram twice daily to all patients. HCG was done after 15 
days of IUI. Clinical pregnancy was confirmed by visualization of cardiac activity on TVS 15 days after positive HCG.

Primary outcome was clinical pregnancy rate in both the groups. Secondary outcome majors were ovulation rate, total days of induction till ovulation, mono V / S multifollicular growth and endometrial thickness.

\section{Statistical Analysis}

Chi - square and student's ' $t$ ' test was carried out for statistical analysis. Results were expressed as mean and standard deviation. P - Value $<0.05$ was considered significant.

\section{RESULTS}

The study comprised of 160 patients, 80 patients in the clomiphene citrate group and 80 patients in the letrozole group. Table 1 shows demographic characteristics of two groups. There was no statistically significant differences in age, BMI, duration of infertility, type of infertility and cause of infertility between the two groups.

\begin{tabular}{|c|c|c|c|c|}
\hline \multicolumn{2}{|c|}{$\begin{array}{l}\text { Demographic } \\
\text { Characteristics }\end{array}$} & $\begin{array}{l}\text { C C Group } \\
(\mathrm{N}=80)\end{array}$ & $\begin{array}{l}\text { LTZ Group } \\
(\mathrm{N}=\mathrm{80})\end{array}$ & P - Value \\
\hline \multicolumn{2}{|c|}{ Age (Years) } & $25.31 \pm 2.56$ & $26.11 \pm 2.60$ & 0.80 \\
\hline \multicolumn{2}{|c|}{$\mathrm{BMI}\left(\mathrm{Kg} / \mathrm{m}^{2}\right)$} & $25.45 \pm 3.13$ & $25.49 \pm 3.19$ & 0.93 \\
\hline \multicolumn{2}{|c|}{ Duration of Infertility (Years) } & $3.46 \pm 2.12$ & $3.59 \pm 2.33$ & 0.71 \\
\hline \multirow{2}{*}{$\begin{array}{l}\text { Type of } \\
\text { Infertility }\end{array}$} & Primary & $54(67.5 \%)$ & $58(72.5 \%)$ & \multirow[t]{2}{*}{0.49} \\
\hline & Secondary & $26(32.5 \%)$ & $22(27.5 \%)$ & \\
\hline \multirow{3}{*}{$\begin{array}{l}\text { Cause of } \\
\text { Infertility }\end{array}$} & Mild PCOS & $28(35 \%)$ & $30(37.5 \%)$ & 0.74 \\
\hline & Male Factor & $32(40 \%)$ & $35(43.75 \%)$ & 0.63 \\
\hline & Unexplained & $20(25 \%)$ & $15(18.75 \%)$ & 0.34 \\
\hline
\end{tabular}

Table 2 shows that the rate of multiple follicular development was statistically significantly higher in the clomiphene citrate group ( $43.75 \% \mathrm{~V} / \mathrm{s} 25 \%$, P - 0.012). There was no difference in total days till ovulation and ET between the clomiphene citrate and letrozole group.

\begin{tabular}{|cccccc|}
\hline $\begin{array}{c}\text { Follicular } \\
\text { Development and } \\
\text { days till ovulation } \\
\text { Mono follicular } \\
\text { Development }\end{array}$ & $\begin{array}{c}\text { Clomiphene } \\
\text { Citrate (C. C.) } \\
\text { Group (N - 80) }\end{array}$ & $\begin{array}{c}\text { LTZ Group } \\
\text { (N - 80) }\end{array}$ & P - Value \\
$\begin{array}{c}\text { Multi follicular } \\
\text { development }\end{array}$ & 35 & $56.25 \%$ & 60 & $75 \%$ & 0.0125 \\
Total days to ovulation & $14.1 \pm 3.23$ & $43.75 \%$ & 20 & $25 \%$ & 0.012 \\
\hline ET (mm) & $8.82 \pm 2.02$ & \multicolumn{2}{c}{$13.8 \pm 2.80$} & 0.53 \\
\hline Table 2. Follicular Development, ET and Days till Ovulation \\
\hline
\end{tabular}

Table 3 shows the ovulation rate of $71.25 \%$ in clomiphene citrate group and $85 \%$ in letrozole group. (P - 0.035). The clinical pregnancy rate was $10 \%$ in clomiphene citrate group and $22.5 \%$ in letrozole group which was statistically significant ( $\mathrm{P}$ - 0.032)

\begin{tabular}{|cccccc|}
\hline & $\begin{array}{c}\text { Clomiphene } \\
\text { Citrate group } \\
(\mathbf{N}-\mathbf{8 0})\end{array}$ & \multicolumn{2}{c|}{$\begin{array}{c}\text { LTZ Group } \\
(\mathbf{N}-\mathbf{8 0})\end{array}$} & P - Value \\
\hline $\begin{array}{c}\text { Ovulation rate } \\
\text { Clinical pregnancy rate } \\
\text { (CPR) }\end{array}$ & $57 / 23$ & $71.25 \%$ & $68 / 12$ & $85 \%$ & 0.035 \\
\hline Table 3. Ovulation and Clinical Pregnancy & Rate among Two Groups \\
\hline
\end{tabular}

\section{DISCUSSION}

Clomiphene citrate is still considered as first line ovulation induction drug in cases where controlled ovarian stimulation is needed like mild PCOS, mild endometriosis, mild to moderate male factor, unexplained infertility and IUI cycles. Endometrial thinning and poor cervical mucus are the main disadvantages with clomiphene citrate, responsible for low success rate. Clomiphene resistance is seen in $15-20 \%$ cases of PCOS. To avoid these adverse effects of clomiphene citrate, letrozole is taken as an alternative drug with advantage of shorter induction time, better endometrial thickness \& cervical mucus quality, monofollicular growth and better pregnancy rate. Letrozole not only increases the FSH release by pitutary but it also increases the follicular sensitivity to FSH through amplification of FSH receptor gene expression.

In our study, the total days of induction till ovulation were $14.1 \pm 3.23$ in clomiphene citrate and $13.8 \pm 2.80$ in letrozole group, though less in letrozole group but statistically not significant. This is comparable to the study of mitwally and casper, ${ }^{13}$ who also found no significant difference in total days till HCG between clomiphene citrate and letrozole $(14.8 \pm 2.7$ Vs $14.2 \pm 2.1$ ). Sujata kar et al. ${ }^{14}$ in her study of PCOS patients also found no difference (C.C.14.2 \pm 3.41 and LTZ $13.13 \pm 2.99$, P - 0.24).

In our study, the mean ET was $8.82 \pm 2.02$ in clomiphene citrate group while $9.02 \pm 2.32$ in letrozole group. It was also slightly higher in letrozole group but statistically not significant (P - 0.56). This was comparable to study of Jee et al. ${ }^{15}$ (LTZ $9.3 \pm 1.7$ Vs C.C. $9.1 \pm 1.7$, NS) and Abu Hashim et al. ${ }^{15}$ (LTZ $8.8 \pm 1.2$, Vs C.C. $8.2 \pm 0.09$, P - 0.53) showing a non significant increase in ET on the day of HCG in the LTZ group Sujata kar et al. ${ }^{14}$ also found slightly higher ET in letrozole group ( $7.65 \pm 2.1$ Vs $7.61 \pm 1.96$, P -0.91$)$, though less than our study. Studies that found letrozole associated with greater endometrial thickness were those of Akbari et al. ${ }^{16}$ (LTZ 9.08 \pm 1.2 Vs C.C. + HMG $8.1 \pm 1.9$, P - 0.0001), Mitwally and Casper ${ }^{13}$ (LTZ 8.1 \pm 1.4 Vs C.C. $6.2 \pm 2.5$, P - <0.01) Davar et al. ${ }^{17}$ (LTZ 6.9 \pm 2.2 Vs C.C. $7.8 \pm 1.8$, NS) found nonsiginificant increase of ET in clomiphene citrate group.

In our study, ovulation rate was $71.25 \%$ in clomiphene citrate group while $85 \%$ in letrozole group, which is statistically significant $(P-0.035)$. This is similar to the study of M. Zeinalzadeh et al. ${ }^{18}$ who reported higher ovulation rate in letrozole group (86 \% Vs $72 \%$, P - 0.07). Sujata kar et al. ${ }^{14}$ in PCO patients showed better ovulation rate with letrozole (73.08 \% Vs $60.78 \%$, P0.39) but not significant statistically. While studies by Bayar et al. ${ }^{19}$ (C.C. $74.7 \%$ Vs LTZ $65.7 \%$ ) and Zawad et al. ${ }^{20}$ (C.C. 87.33 \% Vs LTZ $82.66 \%$ ) found better ovulation rate with clomiphene citrate.

In our study, multifollicular development was statistically significantly higher in clomiphene citrate group as compared to letrozole (C. C. 40 \% Vs LTZ $22.5 \%$, P - 0.016). Total number of follicles were higher in clomiphene citrate group as compared to LTZ in the study of Abu Hashim et al. ${ }^{15}$ (2.8 \pm 0.04 Vs $1.4 \pm 0.02, \mathrm{P}-0.042)$, Badaway et al. ${ }^{21}(3.1 \pm 0.36$ Vs $1.6 \pm$ $0.41, \mathrm{P}-0.045)$

Akbari et al. ${ }^{16}(2.2 \pm 0.68$ Vs $2.02 \pm 0.63, \mathrm{p}-0.025)$, Davar et al. ${ }^{17}(5.45 \pm 4.2 \mathrm{Vs} 3.07 \pm 2.1, \mathrm{P}-0.01)$ and Jawad et al. ${ }^{20}(1.44$ \pm 0.56 Vs $1.13 \pm 0.32, \mathrm{P}-0.001)$. Akbari et al. also used gonadotropins with clomiphene citrate. Total number of 
follicles were significantly greater in C. C. group in the study of Badaway et al. ${ }^{21}$ ( $4.1 \pm 0.46$ Vs $2.6 \pm 0.43$ ) when combined with gonadotropins. While study by fozan et al. ${ }^{22}$ (C.C. $1.1 \pm 0.05 \mathrm{Vs}$ LTZ $1.4 \pm 0.7$ ), Hyon Yun et al. ${ }^{23}$ (C.C. $1.44 \pm 0.88$ Vs LTZ $1.53 \pm$ 0.89 , P - 0.432), Barroso et al. ${ }^{24}$ (C.C. $1.9 \pm 0.5$ Vs LTZ $2.1 \pm 0.9$, NS) found no significant difference between two groups.

Sujata kar et al. ${ }^{14}$ in PCOS patients also observed that multifollicular development was significantly higher in clomiphene citrate group (45.16 \% Vs $20.51 \%$, P0.027). The mono follicular development was higher in letrozole group (75 \% Vs $56.25 \%$, P - 0.0125) in our study.

In our study, the clinical pregnancy rate was significantly higher in letrozole group as compared to clomiphene citrate group (22.5 \% Vs $10 \%$, P - 0.0325) while most of the studies showed comparable pregnancy rates in both the groups after IUI. The clinical pregnancy rate per cycle and the cumulative pregnancy rate after four cycles were comparable $(15.9 \%$ Vs $14.5 \%, \mathrm{P}-0.82$ and $64.7 \%$ Vs $57.2 \%, \mathrm{P}-0.71$ ) in letrozole and clomiphene citrate group respectively in a study by Abu Hashim et al. ${ }^{15}$ but they included only minimal to mild endometriosis cases in their study. Similarly the CPR was comparable between two groups in study by Akbari et al. ${ }^{16}$ (LTZ $21.3 \%$ Vs C.C. $13.8 \%$, P - 0.146), Barroso et al. ${ }^{24}$ (LTZ $23.8 \%$ Vs C.C. $20 \%$, NS) All of them used gonadotropins also.

The clinical pregnancy rate was comparable and higher in clomiphene citrate group (18.3\% Vs $12.2 \%$, p - 0.177) in study by Bo Hyon et al. ${ }^{23}$ but they used gonadotropins also in both groups. CPR was quite low but comparable in the study of fozan et al. ${ }^{22}$ (LTZ $11.5 \%$ Vs C.C. $8.9 \%$ ) Sammour et al. ${ }^{24}$ (LTZ - $16.7 \%$ Vs C.C. $5.6 \%$, P - 0.55).

\section{CONCLUSIONS}

The pharmacodynamics of LTZ (does not deplete estrogen receptor, has short half life and intact hypothalmopitutary axis) results in improved endometrial thickness and cervical mucus, mono follicular growth and better ovulation rate. Therefore the clinical pregnancy rate is also better in letrozole group in our study. Letrozole is a better first line drug as compared to clomiphene citrate for super ovulation in IUI cycles though further larger studies are needed to confirm this.

Data sharing statement provided by the authors is available with the full text of this article at jemds.com.

Financial or other competing interests: None.

Disclosure forms provided by the authors are available with the full text of this article at jemds.com.

\section{REFERENCES}

[1] Cohlen BJ, Vandekerckhove P, Te Velde ER, et al. Timed intercourse versus intra-uterine insemination with or without ovarian hyperstimulation for subfertility in men. Cochrane Database Syst Rev 2007;3:CD000360.

[2] Guzick DS, Carson SA, Coutifaris C, et al. Efficacy of superovulation and intrauterine insemination in the treatment of infertility. N Engl J Med 1999;340(3):177-83.

[3] Kistner RW. Induction of ovulation with clomiphene citrate (clomid). Obstet Gynecol Surv 1965;20(6):873900.
[4] Dickey RP, Holtkamp DE. Development, pharmacology and clinical experience with clomiphene citrate. Hum Reprod Update 1996;2(6):483-506.

[5] Mitwally MF, Biljan MM, Casper RF. Pregnancy outcome after the use of an aromatase inhibitor for ovarian stimulation. Am J Obstet Gynecol 2005;192(2):381-6.

[6] Massai MR, De Ziegler D, Lesobre V, et al. Clomiphene citrate affects cervical mucus and endometrial morphology independently of the changes in plasma hormonal levels induced by multiple follicular recruitment. Fertil Steril 1993;59(6):1179-86.

[7] Naftolin F, MacLusky NJ. Aromatization Hypothesis Revisisted. In: Serio M, ed. Differentiation: basic and clinical aspects. New York: Raven Press 1984:79-91.

[8] Vendola K, Zhou J, Wang J, et al. Androgens promote oocyte insulin-like growth factor I expression and initiation of follicle development in the primate ovary. Biol Reprod 1999;61(2):353-7.

[9] Biljan MM, Hemmings R, Brassard N. The outcome of 150 babies following the treatment with letrozole or letrozole and gonadotropins. Fertil Steril 2005;84(Suppl 1):S95.

[10] Tulandi T, Martin J, Al-Fadhli R, et al. Congenital malformations among 911 newborns conceived after infertility treatment with letrozole or clomiphene citrate. Fertil Steril 2006;85(6):1761-5.

[11] Reefhuis J, Honein MA, Schieve LA, et al. National birth defects prevention study. Use of clomiphene citrate and birth defects, National Birth Defects prevention study, 1997-2005. Hum Reprod 2011;26(2):451-7.

[12] Atay V, Cam C, Muhcu M, et al. Comparison of letrozole and clomiphene citrate in women with polycystic ovaries undergoing ovarian stimulation. J Int Med Res 2006;34(1):73-7.

[13] Mitwally M, Casper R. Use of aromatase inhibitor for ovulation induction in patients with an inadequate response to clomiphene citrate. Fertil Steril 2001;75(2):305-9.

[14] Kar S. Clomiphene citrate or letrozole as first-line ovulation induction drug in infertile PCOS women: a prospective randomized trial. J Hum Reprod Sci 2012;5(3):262-5.

[15] Hashim HA, Rakhawy ME, Elaal IA. Randomized comparison of superovulation with letrozole vs. clomiphene citrate in an IUI program for women with recently surgically treated minimal to mild endometriosis. Acta Obstet Gynecol Scand 2012;91(3):338-45.

[16] Akbari S, Roozbahani MA, Roozbahani FA. Comparing of letrozole versus clomiphene citrate combined with gonadotropins in intrauterine insemination cycles. Iran J Reprod Med 2012;10(1):29-32.

[17] Davar R, Javedani M, Fallahzadeh MH. Metforminletrozole in comparison with metformin-clomiphene citrate in clomiphene-resistance PCOS patients undergoing IUI. Iran J Reprod Med 2011;9(1)31-6.

[18] Zeinalzadeh M, Basirat Z, Esmalpour M. Efficacy of letrozole in ovulation indication compared to that of clomiphene citrate in patients with polycystic ovarian syndrome. J Reprod Med 2010;55(1-2):36-40. 
[19] Bayar U, Tanriverdi HA, Aykut B, et al. Letrozole vs. clomiphene citrate in patients with ovulatory infertility. Fertil Steril 2006;85(4):1045-8.

[20] Jawad AK, Ali MS, Jawad RK. Comparison of efficacy of letrozole and clomiphene citrate for induction of ovulation. Zanco J Med Sci 2020;24(1):21-7.

[21] Badawy A, Elnashar A, Totongy M. Clomiphene citrate or aromatase inhibitors combined with gonadotropins for superovulation in women undergoing intrauterine insemination: a prospective randomized trial. J Obstet Gynaecol 2010;30(6):617-21.

[22] Al-Fozan H, Al-Khadouri M, Seang LT, et al. A randomized trial of letrozole versus clomiphene citrate in women undergoing superovulation. Fertil Steril 2004;82(6):1561-3.

[23] Yun BH, Chon SJ, Park JH. et al. Minimal stimulation using gonadotropin combined with clomiphene citrate or letrozole for intrauterine insemination. Yonsei Med J 2015;56(2):490-6.

[24] Barroso G, Menocal G, Felix H, et al. Comparison of the efficacy of the aromatase inhibitor letrozole and clomiphene citrate as adjuvants to recombinant folliclestimulating hormone in controlled ovarian hyperstimulation: a prospective, randomized, blinded clinical trial. Fertil Steril 2006;86(5):1428-31. 